\title{
The prevalence of hypertension and cardiovascular risks in children with renal scars secondary to urinary tract infection
}

\author{
Nakysa Hooman, Roya Isa-Tafreshi, Seyed-Hassan Mostafavi, Farideh Halladji, Azita Tavasoli, \\ Minoo Saeidy, Mitra Mehrazma, Hasan Otukesh*
}

Hypertension is a late outcome of reflux nephropathy and renal parenchymal scar secondary to urinary tract infection (UTI). We presumed that it might be detected much earlier after episodes of UTI and the associated cardiovascular risk factors assessed. Between 2009 and 2011, 85 (67 female and 18 male) children aged 5-15 years with a history of febrile UTI, followed-up for at least one year from the first episode of febrile UTI, were enrolled in the study. The variables included 24-hour ambulatory blood pressure monitoring (ABPM), echocardiography, carotid sonography, renal 99mcTc-DMSA, glomerular filtration rate, and microalbuminuria. Masked hypertension was detected in 18.8\%, hypertension in $7.1 \%$ and white coat hypertension in $9.4 \%$ of cases. Prehypertension was seen in $20 \%$ of children. Out of 85 cases, $43.5 \%$ were non-dippers. Out of 56 children with hypertensive and prehypertensive parameters on ABPM, 9.1\% showed left ventricular mass index $>51 \mathrm{~g} / \mathrm{m}^{2.7}$ ( $p>0.05$ ). Significant correlation was only recorded between abnormal blood pressure and the severity of renal parenchymal scar ( $p<0.05)$. In conclusion, ABPM is suggested for early detection of masked hypertension and abnormal blood pressure pattern in all normotensive children with a history of recurrent UTI.

Keywords: blood pressure monitoring, ambulatory; urinary tract infections; hypertrophy, left ventricular; carotid intima-media thickness; early diagnosis

\section{INTRODUCTION}

Ambulatory blood pressure monitoring (ABPM) is a sensitive tool for early detection of hypertension and its finding is highly correlated to cardiovascular morbidity in adults. There is controversy about hypertension as a late sequel of urinary tract infection (UTI). Our previous study showed the rate of renal parenchymal scars after first episode of acute pyelonephritis to be about $42 \%$ (1). The prevalence of renal scars in hypertensive children is $21 \%$ (2). Longitudinal studies estimate 3\% to 30\% increment of the occurrence of hypertension after longtime follow up of patients with a history of parenchymal scarring secondary to vesicoureteral reflux (VUR) and UTI during childhood (3-5). These studies are based on conventional blood pressure measurements. The mechanism of hypertension is not clearly defined but segmental ischemia and renin-angiotensin activation have been suggested. Plasma renin activity is raised in children with pyelonephritic scarring regardless of the absolute value of blood pressure (6). The patients with renal parenchy- ma scar seem to have lower glomerular filtration rate (GFR) and activated renin- angiotensin-aldosterone system in comparison to controls. The capability of tubular handling of sodium and water in response to fluid expansion is intact (7). On the other hand, a cohort based on ABPM in those with at least 10-year history of childhood UTI shows a lower incidence of hypertension in scarring with a higher level of atrial natriuretic peptide (8).

We presumed that the utilization of ABPM would help detect abnormal blood pressure pattern in a shorter follow-up

* Iran University of Medical Sceinces, Tehran, Iran

\section{Correspondence to:}

Nakysa Hooman, Iran University of Medical Sceinces, Tehran, Iran, e-mail: nakisa45@yahoo.com

* Abstract of this paper was accepted for oral presentation at the $22^{\text {nd }}$ European Meeting on Hypertension and Cardiovascular Protection, 26-29 April, 2012 in London, United Kingdom, April 26-29, 2012

Primljeno/Received: 4. 1. 2015., Prihvaćeno/Accepted: 8. 4. 2015. 
survey of children with a history of acute pyelonephritis. Finding evidence for this hypothesis will be a clue for wider utilization of ABPM in children with a history of acute pyelonephritis to detect masked hypertension. The aim of this study was to assess the correlation between blood pressure and target organ damages in children with different degrees of renal parenchyma scars secondary to UTI.

\section{PATIENTS AND METHODS}

Between 2009 and 2011, 85 (67 female and 18 male) children aged 5-15 years with a history of UTI were enrolled in the study. Participants were children with a history of febrile UTI followed-up routinely in the pediatric nephrology clinic. UTI was confirmed by clinical symptoms and signs in favor of pyelonephritis, laboratory tests including complete blood count, erythrocyte sedimentation rate, C-reactive protein, and positive urine culture. All children were questioned about the presence of lower urinary tract symptoms. Weight, height and blood pressure were measured by conventional methods. Body mass index $(\mathrm{BMI}) \geq 95^{\text {th }}$ percentile was defined as overweight. Puberty was assessed by the Sexual Maturation Rating (SMR) score and classified into prepubertal (stages $\leq 4$ ) and pubertal (stage $>4$ ). Urine analysis and urine culture were done at each visit. At first, all children visited the clinic every month for six months, then every three months until being free from UTI for at least one year. The inclusion criteria covered all children aged $\geq 5$ years with a history of UTI that were followed-up for at least one year from the first episode of febrile UTI (single or recurrent UTI included). Exclusion criteria were obesity (BMI $>95^{\text {th }}$ percentile), any endocrine disorders, any antihypertensive, corticosteroid or nonsteroid anti-inflammatory medications, neurogenic bladder, obstructive uropathy, chronic kidney disease stage more than two (eGFR $<60 \mathrm{~mL}$ / $\mathrm{min} / 1.73 \mathrm{~m}^{2}$ ), acute UTI at the time of the study, and children unable to tolerate ABPM.

The study protocol followed the guidelines of the declaration of Helsinki and Tokyo for humans and was approved by the institutional human experimentation committee of the Iran University of Medical Sciences. After obtaining consent from the parents and patients, all cases underwent 24-hour ABPM. All ABPM procedures were performed using a validated device from Tiba Medical Ambluo 2400 Inc. (Portland, Oregon, USA) with oscillometric monitor and actigraphy $(9,10)$. Appropriate cuff was used over non-dominant arm. The patient was requested to avoid excessive exercise and keep the arm still during measurements. The device was scheduled to measure blood pressure every 30 minutes at daytimes and every hour at night times. At least 35 correct measurements were considered sufficient. The mean systolic blood pressure (SBP), mean diastolic blood pressure
(DBP), mean arterial pressure (MAP), SBP load, DBP load during 24 hours while awake and during sleep were analyzed separately. We used normalized blood pressure references produced by the German working group for defining $95^{\text {th }}$ percentile blood pressure (11). To diagnose hypertension, we considered that both criteria of blood pressure (SBP and DBP) load of more than 25\% and mean blood pressure index (SBP, DBP, or MAP) equal or more than one existed. Blood pressure index was calculated by dividing the mean blood pressure (SBP, DBP, or MAP) to $95^{\text {th }}$ percentile blood pressure (SBP, DBP, or MAP) for age, sex and height. Prehypertension was defined by the mean blood pressure $\geq 90^{\text {th }}$ percentile and $<95^{\text {th }}$ percentile for age, sex and height; or normal mean blood pressure with blood pressure load of $>25 \%$. Dipper was defined by $\geq 10 \%$ drop of the mean arterial blood pressure (MAP, SBP, or DBP) level from day to night. When office blood pressure was normal and less than 95 percentile for age, sex and height, but ABPM showed concordance with hypertension criteria, the patient was classified as masked hypertension (12). Standard transthoracic echocardiography was performed using a Vivid 3 (General Electric Medical Systems, Horten, Norway, 2.5-7 MHZ probe) device equipped with tissue Doppler technology, as we have previously described (13). All measurements were carried out by one examiner who was blind to the status of the subjects. Left ventricular mass (LVM) was assessed by using two dimensional directed M-mode echocardiography. Then, LVM index (LVMI) was calculated to evaluate left ventricular hypertrophy (LVH). LVM index of $38-51 \mathrm{~g} / \mathrm{m}^{2.7}$ was defined as the beginning of $L V H$ and LVM index $>51 \mathrm{~g} / \mathrm{m}^{2.7}$ was considered as LVH. The intima-media thickness of the common carotid artery (cIMT) on each side was measured by a radiologist using a GE Logic 500 sonography system with two $7.5 \mathrm{MHz}$ linear and $5 \mathrm{MHz}$ convex probes. We have previously described the method of CIMT measurement in detail (14).

Urinary tract infection is defined by the presence of acute pyelonephritis symptoms and positive urine culture based on mid stream growth of more than $10^{5}$ single colony or more than $10^{4}$ by catheter (1). All children had $99 \mathrm{mTC}$ DMSA for detection of parenchymal scarring at least 6 months after acute UTI. The method included injection of $37 \mathrm{MBq}$ of 99mTc-DMSA intravenously and multiple projections were taken 3 to 4 hours later. Renal parenchymal scar was classified to type I: no more than two scarred areas, or persistence of the photopenic region; type II: more than two scars with some areas of normal parenchyma in-between them; type III: generalized damage to the whole kidney similar to obstruction nephropathy; type IV: end-stage 'shrunken' kidney (kidney with little or no uptake by 99 mTc-DMSA scan; <10\% of the overall function) $(15,16)$. The $99 m-T c$ DMSA was re- 
TABLE 1. Demographic data of children at the time of study. Data presented as median (range)

\begin{tabular}{|c|c|c|c|c|c|}
\hline \multirow[b]{2}{*}{ Variable } & \multicolumn{4}{|c|}{ DMSA classification } & \multirow[b]{2}{*}{$\mathrm{p}$-value } \\
\hline & $\begin{array}{l}\text { Normal } \\
n=24\end{array}$ & $\begin{array}{l}\mathrm{l} \\
\mathrm{n}=26\end{array}$ & $\begin{array}{l}\text { II } \\
n=15\end{array}$ & $\begin{array}{l}\text { III-V } \\
n=20\end{array}$ & \\
\hline Age at first UTI (yrs) & $1(0-8.5)$ & $3.5(0.1-6)$ & $3(1.5-9)$ & $3(0.3-6)$ & 0.05 \\
\hline $\begin{array}{l}\text { Sex* } \\
\text { Female, n (\%) } \\
\text { Male, n \%) }\end{array}$ & $\begin{array}{l}21(88) \\
3(13)\end{array}$ & $\begin{array}{l}22(85) \\
4(15)\end{array}$ & $\begin{array}{l}14(93) \\
1(7)\end{array}$ & $\begin{array}{l}10(50) \\
10(50)\end{array}$ & 0.004 \\
\hline $\mathrm{BMI}$ & $15(10-23)$ & $15.4(10.7-25)$ & $16(11-21)$ & $15(6-20)$ & NS \\
\hline $\mathrm{BMI}>85^{\text {th }}$ percentile, $\mathrm{n}(\%)^{*}$ & $6(25)$ & $7(27)$ & $6(40)$ & $5(25)$ & NS \\
\hline Weight (kg) & $21(14-52)$ & $24(13-63)$ & $29.5(13-46)$ & $22(13-50)$ & NS \\
\hline Height (cm) & $124(106-161)$ & $124(93-158)$ & 135 (107158) & $131(99-163)$ & NS \\
\hline SBP-causal (mm Hg) & $100(70-130)$ & $100(76-120)$ & $100(80-120)$ & $102.5(60-130)$ & NS \\
\hline DBP-causal (mm Hg) & $60(40-80)$ & $63(30-85)$ & $68(40-80)$ & $70(40-100)$ & 0.047 \\
\hline Plasma Cr (mg/dL) & $0.6(0.4-1)$ & $0.6(0.3-0.8)$ & $0.6(0.4-0.8)$ & $0.7(0.4-0.9)$ & 0.034 \\
\hline $\mathrm{GFR}\left(\mathrm{mL} / \mathrm{min} / 1.73 \mathrm{~m}^{2}\right)$ & $118(68-163)$ & $109(78-220)$ & $114(82-173)$ & $96(70-158)$ & 0.044 \\
\hline $\begin{array}{l}\text { GFR classification, n (\%)* } \\
>90 \\
60-90\end{array}$ & $\begin{array}{l}20(83) \\
4(17)\end{array}$ & $\begin{array}{l}23(88.5) \\
3(11.5)\end{array}$ & $\begin{array}{l}14(93.3) \\
1(6.7)\end{array}$ & $\begin{array}{l}10(50) \\
10(50)\end{array}$ & 0.009 \\
\hline Follow up (yrs) & $3.4(1-10)$ & $5(1-12)$ & $4.2(1-8.5)$ & $5(1-10)$ & NS \\
\hline Familial RF, n (\%)* & $4(16.7)$ & $6(23)$ & $3(20)$ & $3(15.8)$ & NS \\
\hline Single kidney, n (\%)* & $1(4)$ & $2(7.7)$ & 0 & $3(15)$ & NS \\
\hline Number of UTIs & $1(1-4)$ & $1(1-3)$ & $1(1-3)$ & $1(1-4)$ & NS \\
\hline $\begin{array}{l}\text { VUR, n (\%)* } \\
\text { • severe } \\
\text { • moderate } \\
\text { • mild } \\
\cdot \text { - normal }\end{array}$ & $\begin{array}{l}0 \\
3(14) \\
4(18) \\
15(68)\end{array}$ & $\begin{array}{l}0 \\
12(46) \\
2(8) \\
12(46)\end{array}$ & $\begin{array}{l}1(7) \\
8(43) \\
1(7) \\
6(43)\end{array}$ & $\begin{array}{l}11(55) \\
4(20) \\
1(5) \\
4(20)\end{array}$ & $<0.001$ \\
\hline
\end{tabular}

$\mathrm{F}=$ female; $\mathrm{M}=$ male; $\mathrm{BMI}=$ body mass index; $\mathrm{SBP}=$ systolic blood pressure; $\mathrm{DBP}=$ diastolic blood pressure; $\mathrm{Cr}=\mathrm{creatinine}$; $\mathrm{RF}=$ risk factor;

$\mathrm{VUR}=$ vesicoureteral reflux; ${ }^{*}$ number (percentage) analyzed by $\mathrm{X}^{2}$-test

ported by a physician who was unaware of the patients' blood pressure and conditions.

Plasma creatinine was measured by Jaffe method using creatinine kit (Pars Azmoon Co., Tehran, Iran) on a Biolis 24i Premium device (Tokyo Boeki Medical System, Ltd.). GFR calculation was based on serum creatinine using Schwartz formula [0.55xheight (cm)/Pcr]. GFR $>90 \mathrm{~mL} / \mathrm{min} / 1.73 \mathrm{~m}^{2}$ was considered normal, 60-90 mild, 30-60 moderate, and 15-30 severe chronic kidney disease, and $<15$ end stage renal disease. One should be aware that creatinine assessed by Jaffe method may overestimate GFR calculated by Schwarz formula.

Urine microalbumin was assayed by the Binding Site nephelometric kit (MININEPH, Birmingham, UK). Microalbuminuria was defined by the albumin to creatinine excretion of more than $30 \mathrm{mg} / \mathrm{g}$ creatinine. The sample was obtained from the first urine of day.

The frequency, mean, and correlation were evaluated by the $x^{2}$-test, ANOVA test, and Spearman correlation. For variables that were not normally distributed, median and non- parametric tests were used. The level of significance was set at $\mathrm{p}<0.05$.

\section{RESULTS}

Twenty-one of 101 children, mean age $7.6( \pm 2.9)$ years, were excluded because of having neurogenic bladder $(n=1)$, being hypertensive and on medication $(n=1)$, insufficient data of $\operatorname{ABPM}(n=8)$, age less than five years $(n=9)$, and eGFR $<60 \mathrm{~mL} / \mathrm{min} / 1.73 \mathrm{~m}^{2}(\mathrm{n}=2)$. Table 1 shows demographic, laboratory and imaging reports at the start of the study. We categorized children according to the severity of renal parenchymal scars based on 99Tc-DMSA report. As shown in Table 1, the group with more severe renal parenchymal scar was accompanied with higher VUR grade, lower GFR, and higher DBP detected on office check up, and it was more frequent in male gender.

Table 2 shows ABPM results in study children according to renal DMSA classification. Table 3 depicts the frequency of abnormal blood pressure in children with UTI and the correlation of abnormal blood pressures with independent 
TABLE 2. Result of ambulatory blood pressure monitoring in children with history of UTI with and without renal parenchymal scar

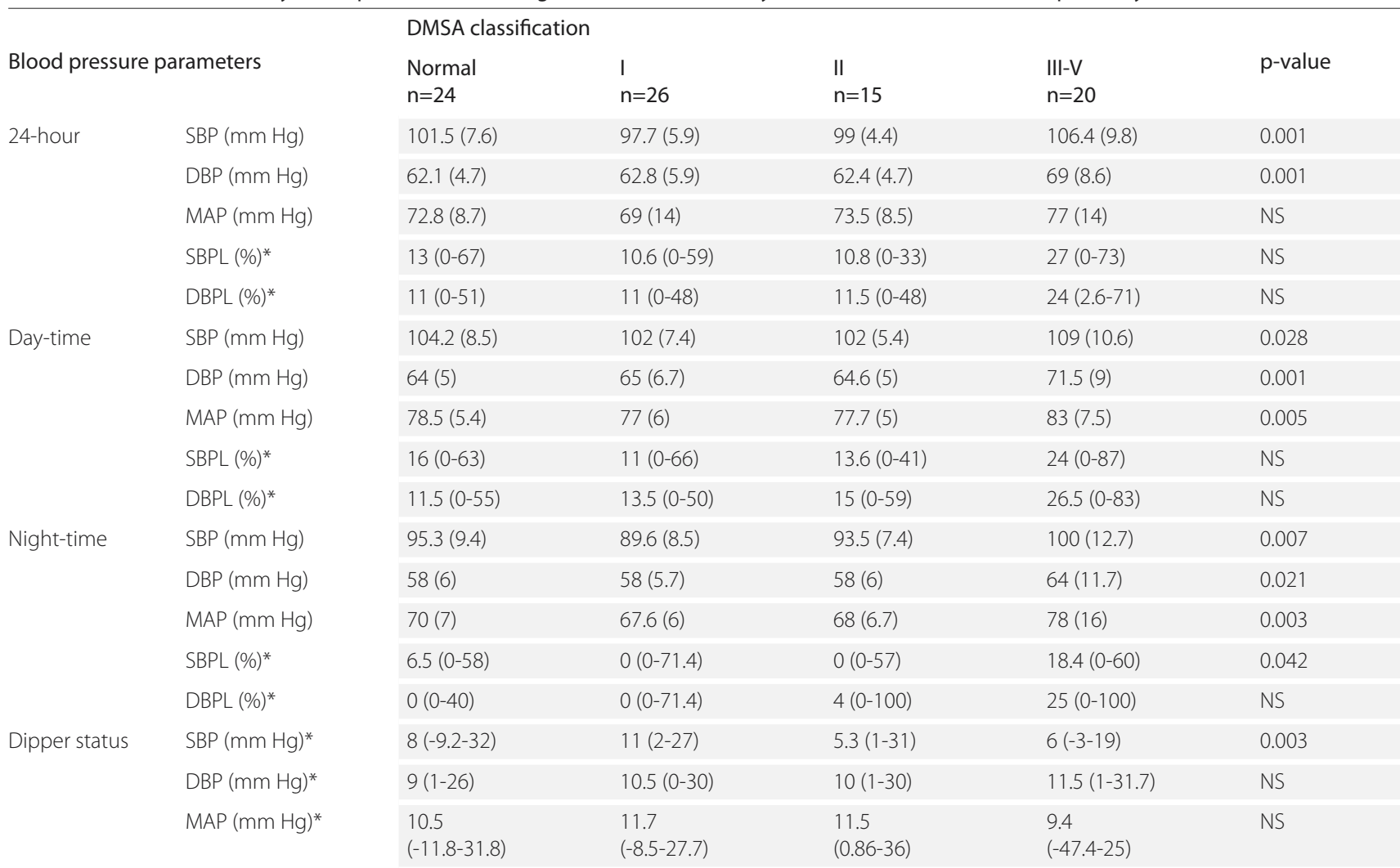

$\mathrm{SBP}=$ systolic blood pressure; DBP = diastolic blood pressure; MAP = mean arterial blood pressure; $\mathrm{SBPL}=$ systolic blood pressure load; DBPL = diastolic blood pressure load; 24-hour = 24-hour monitoring; dipper status = percentage of blood pressure drop at night time; *median (range) analyzed by non-parametric median test

variables. Only the severity of renal parenchymal scars showed correlation with significantly abnormal blood pressure (Figure 1). We did not find any correlation between non-dipper status and different independent variables.

The mean (SD) carotid cIMT was $0.36 \mathrm{~mm}(0.048)$ in hypertensive, $0.33 \mathrm{~mm}(0.068)$ in prehypertensive, and $0.33(0.046)$ in normotensive children ( $p>0.05)$. Overall, office blood pressure detected high blood pressure in 14 children and ABPM detected hypertension in 22 children including four (4.7\%) with high 24-hour blood pressure, and 18 (21.2\%) with night-time hypertension. Comparison of the office blood pressure with ABPM reports revealed that hypertension was confirmed in six (7.1\%) children, eight (9.4\%) had white coat hypertension, and 16 (18.8\%) had masked hypertension. We found that children with masked hypertension had a more severe renal parenchymal scar $(p=0.015)$, but the frequency of VUR, single kidney, or GFR was not different $(p>0.05)$.

\section{DISCUSSION}

The study showed that about $26 \%$ of the children with a history of UTI were hypertensive and 39\% were prehyper- tensive. These children had a higher rate of left ventricular hypertrophy after short term follow-up. ABPM is a sensitive tool for detection of white coat hypertension, masked hypertension, and evaluation of blood pressure pattern. A recent European guideline for the management of hypertension recommends assessing total cardiovascular risk factors in all hypertensive patients. The coexistence of hypertension and cardiovascular risks potentiates each other. The risk factors that might be applicable while evaluating a child for blood pressure include lipid profiles, blood glucose level, smoking habit, and asymptomatic organ damage. Moreover, taking personal and family medical histories are essential steps in initial evaluation of such cases (12). Jacobson et al. studied 30 adults with a history of childhood UTI. Renal scars were detected by intravenous pyelogram. Of these patients, 23\% developed hypertension and 10\% progressed to end stage renal failure $(5,17)$. Köhler et al. conducted a retrospective cohort study on 115 adults with VUR and a history of UTI. Hypertension was detected in $34 \%$ and it was more common in bilateral VUR (18). Another study by Ahmed et al. looked at the prevalence of renal scars in hypertensive children and reported $21 \%$ of hypertensive children having renal scars (2). Contrary to previous studies, 
TABLE 3. Correlation between blood pressure abnormalities and independent factors

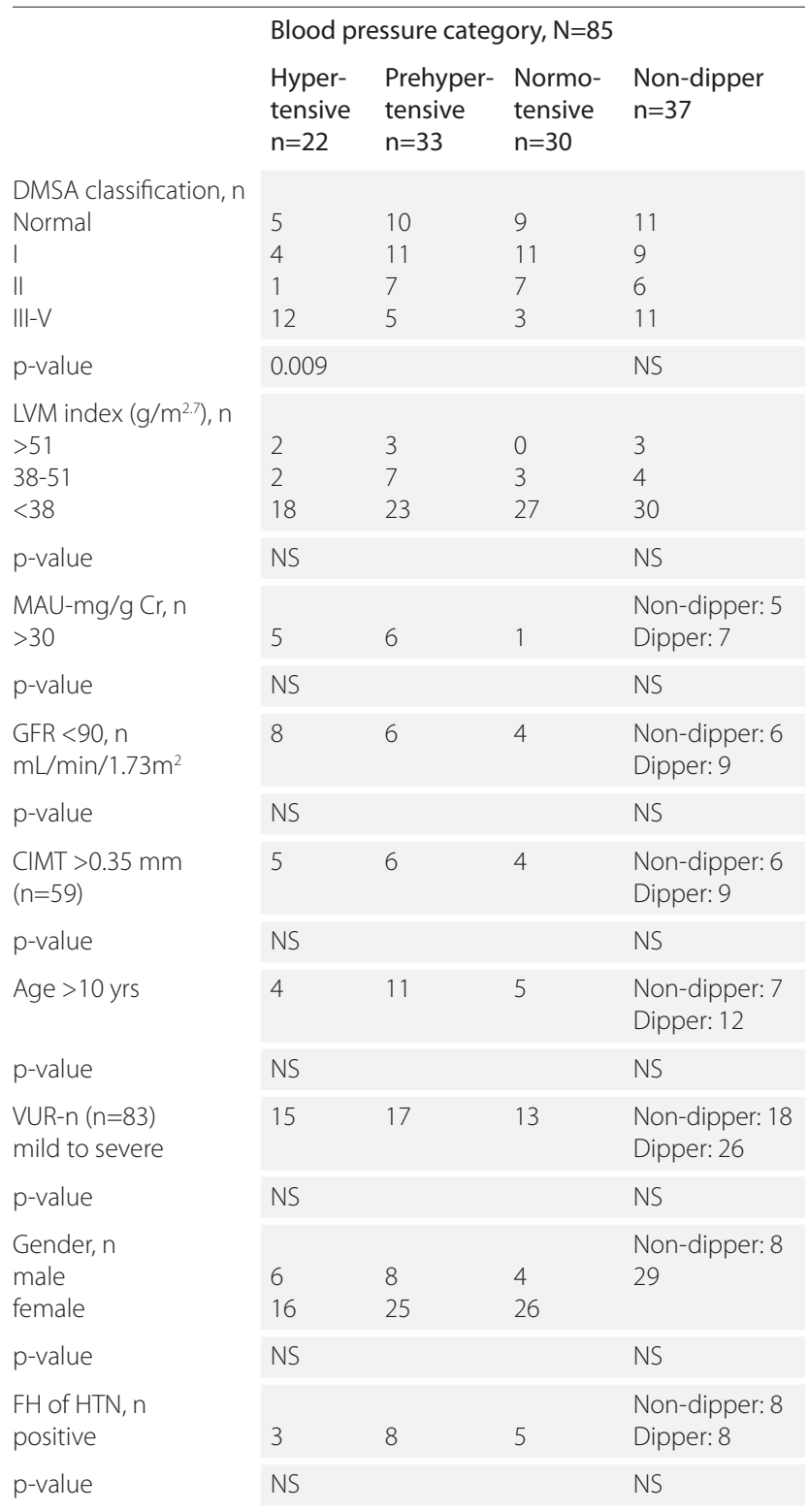

GFR = glomerular filtration rate; $M A U=$ microalbuminuria; $\mathrm{CIMT}=$ carotid intima media thickness; VUR = vesicoureteral reflux; LVM = left ventricular mass; FH of HTN = family history of hypertension

Wennerström et al. found a low risk of hypertension and higher level of atrial natriuretic peptide in long term follow up of 68 children with a history of UTI and non-obstructive renal scar compared to 51 matched controls. The mean SBP and DBP during day, night and 24 hours were not different between the groups (8). It was not in accordance with our results that the mean SBP and DBP during day-time, nighttime and the whole day (24 hours) were higher in children with renal scar. Patzer et al. compared 24-hour ABPM in 61 children with renal scar secondary to recurrent UTI and VUR with 904 healthy children and found higher mean nighttime SBP and DBP in children with scar and lower drop of

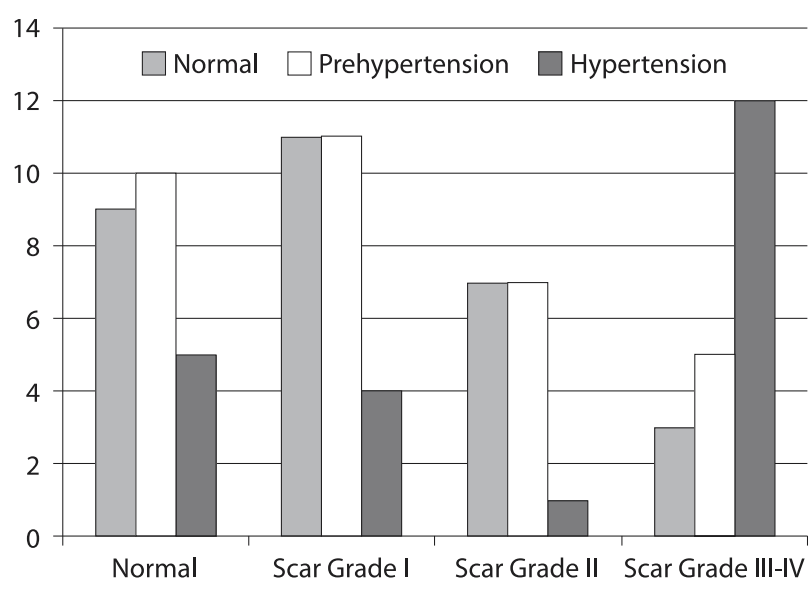

FIGURE 1. The frequency of blood pressure change in different severity of renal scars $(p=0.009)$.

blood pressure at night, which is consistent with our findings (19).

However, we found higher 24-hour blood pressure and nigh-time hypertension in children with more sever scar detected on renal parenchyma scan. Lama et al. report that children with high grade VUR had a higher rate of hypertension detected by ABPM, lower GFR, higher rate of microalbumin excretion, and higher mean plasma renin activity (20). It is consistent with our study, where a statistically significant correlation was found between abnormal blood pressure and the severity of VUR or renal parenchymal scars. However, the mean CIMT was not different among hypertensive, prehypertensive and normal children; patients with abnormal blood pressure had a higher rate of cIMT $>0.35 \mathrm{~mm}$. Lande et al. measured CIMT in 28 children with newly diagnosed essential hypertension and 28 normotensive cases. They found a correlation between abnormal ABPM parameters and CIMT, but this correlation did not exist between ABPM and LVMI (21).

Children who were hypertensive and prehypertensive in ABPM parameters had a significantly higher rate of LVMI $>38 \mathrm{~g} / \mathrm{m}^{2.7}$. It was in accordance with Stabouli et al. who evaluated LVMI and prevalence of LVH in 124 children. They found a significantly higher LVMI in hypertensive and prehypertensive children as compared with normotensive children. The prevalence of LVH was similar in both children with high blood pressure and prehypertensive children (22). Richey et al. measured ABPM and LVMI in 110 children at risk of hypertension and found a significant positive correlation between elevated LVMI and SBP parameters (23). In our study we found a higher prevalence of LVMI and moderate chronic kidney disease in children with abnormal blood pressure on ABPM. Tafreshi et al. measured myocardial performance index by tissue Doppler imaging and found better sensitivity and specificity for early detection of subtle 
abnormalities of left ventricular dysfunction than pulse wave Doppler method (13). More than one-third of patients in our study had prehypertension on ABPM. Urbina et al. supported the argument that even modest elevation in blood pressure has an important effect on the cardiovascular system in adolescents and young adults, analyzing target organ damages such as increased CIMT, LVMI, and carotid dysfunction (24). The absence of control group was one of the limitations of our study.

In conclusion, ABPM for early detection of hypertension and prehypertension is suggested in all normotensive children with a history of recurrent UTI. Serial annual ABPM in these children would help evaluate the pattern of blood pressure in this group.

\section{ACKNOWLEDGMENT}

The study was supported by the Iran University of Medical Sciences, grant number 2242 dated 2009-2010 and grant number 860 dated 2010-2011. We thank Leila Moghiseh and Zahra Saffar for performing ambulatory blood pressure monitoring.

\section{Abbreviations: \\ CIMT - carotid intima media thickness \\ DBP - diastolic blood pressure \\ HTN - hypertension \\ MAP - mean arterial pressure \\ SBP - systolic blood pressure \\ UTI - urinary tract infection}

\section{NOVČANA POTPORA/FUNDING}

Nema/None

\section{ETIČKO ODOBRENJE/ETHICAL APPROVAL \\ Nije potrebno/None}

\section{SUKOB INTERESA/CONFLICT OF INTEREST}

Autori su popunili the Unified Competing Interest form na www.icmje.org/ coi_disclosure.pdf (dostupno na zahtjev) obrazac i izjavljuju: nemaju potporu niti jedne organizacije za objavljeni rad; nemaju financijsku potporu niti jedne organizacije koja bi mogla imati interes za objavu ovog rada u posljednje 3 godine; nemaju drugih veza ili aktivnosti koje bi mogle utjecati na objavljeni rad./All authors have completed the Unified Competing Interest form at www.icmje.org/coi_disclosure.pdf (available on request from the corresponding author) and declare: no support from any organization for the submitted work; no financial relationships with any organizations that might have an interest in the submitted work in the previous 3 years; no other relationships or activities that could appear to have influenced the submitted work.

\section{REFERENCES}

1. Sobouti B, Hooman N, Movahed M. The effect of vitamin E or vitamin A on the prevention of renal scarring in children with acute pyelonephritis. Pediatr Nephrol. 2012;28:277-83.

2. Ahmed M, Eggleston D, Kapur G, Jain A, Valentini RP, Mattoo TK. Dimercaptosuccinic acid (DMSA) renal scan in the evaluation of hypertension in children. Pediatr Nephrol. 2008;23:435-8.
3. Smellie JM, Prescod NP, Shaw PJ, Risdon RA, Bryant TN. Childhood reflux and urinary infection: a follow up of 10-41 years in 226 adults. Pediatr Nephrol. 1998;12:727-36.

4. Silva JM, Santos Diniz JS, Marino VS, et al. Clinical course of 735 children and adolescents with primary vesicoureteral reflux. Pediatr Nephrol. 2006;21:981-8.

5. Jacobson SH, EklÖf O, Eriksson CG, Lins LE, Tidgren B, Winberg J. Development of hypertension and uraemia after pyelonephritis in childhood: 27 years follow up. BMJ. 1989;299:703-6.

6. Savage JM, Dillon MJ, Shah V, Barratt TM, Williams DI. Renin and blood-pressure in children with renal scarring and vesicoureteric reflux. Lancet. 1978;2:441-4.

7. Jacobson SH, Kjellstrand CM, Lins LE. Role of hypervolemia and renin in the blood pressure control of patients with pyelonephritis renal scarring. Acta Med Scand. 1988;224:47-53.

8. Wennerström M, Hansson S, Hedner T, Himmelmann A, Jodal U. Ambulatory blood pressure 16-26 years after the first urinary tract infection in childhood. J Hypertens. 2000;18:485-91.

9. Alpert BS. Validation of the Tiba Medical Ambulo 2400 ambulatory blood pressure monitor to the ISO Standard and BHS protocol. Blood Press Monit. 2010;15:275-7

10. Tabatabaie M, Hooman N, Arjmandi-Rafsanjani K, Isa-Tafreshi R. Ambulatory blood pressure monitoring for children with Beta-thalasemia major. a preliminary report. Iran J Kidney Dis. 2013;7:299-303.

11. Wühl E, Witte K, Soergel M, Mehls O, Schaefer F, German Working Group on Pediatric Hypertension. Distribution of 24-h ambulatory blood pressure in children: normalized reference values and role of body dimensions. J Hypertens. 2002;20:1995-2007.

12. Mancia G, Fagard R, Narkiewicz K, et al; Task Force Members. 2013 ESH/ESC Guidelines for the management of arterial hypertension: the Task Force for the management of arterial hypertension of the European Society of Hypertension (ESH) and of the European Society of Cardiology (ESC). J Hypertens. 2013;31:1281-357.

13. Tafreshi Rl, Human N, Otukesh $\mathrm{H}$, Nikavar A. Evaluation of combined left ventricular function using the myocardial performance index in children with chronic kidney disease. Echocardiography. 2011;28:97-103.

14. Hooman N, Isa-Tafreshi R, Otukesh H, Mostafavi SH, Hallaji F. Carotid artery function in children with idiopathic nephrotic syndrome. Nefrologia. 2013;33:650-6.

15. Rushton HG. The evaluation of acute pyelonephritis and renal scarring with technetium 99m- dimercaptosuccinic acid renal sintigraphy: evolving concepts and future directions. Pediatr Nephrol. 1997;11:108-20.

16. Patel K, Charron M, Hoberman A, Brown MI, Rogers KD. Intra-and interobserver variability in interpretation of DMSA scans using a set of standardized criteria. Pediatr Radiol. 1993;23:506-9.

17. Jacobson SH, Eklof O, Lins LE, Wikstad I, Winberg J. Long-term prognosis of post-infectious renal scarring in relation to radiological findings in childhood- a 27-year follow-up. Pediatr Nephrol. 1992;6:19-24.

18. Köhle J, Tencer J, Thysell H, Forsberg L. Vesicoureteral reflux diagnosed in adulthood. Incidence of urinary tract infections, hypertension, proteinuria, back pain and renal calculi. Nephrol Dial Transplant. 1997;12:2580-7.

19. Patzer L, Seeman T, Luck C, Wühl E, Janda J, Misselwitz J. Day- and night-time blood pressure elevation in children with higher grades of renal scarring. J Pediatr. 2003;142:117-22.

20. Lama G, Tedesco MA, Graziano L, et al. Reflux nephropathy and hypertension: correlation with the progression of renal damage. Pediatr Nephrol. 2003;18:241-5.

21. Lande MB, Carson NL, Roy J, Meagher CC. Effects of childhood primary hypertension on carotid intima media thickness: a matched controlled study. Hypertension. 2006;48:40-4.

22. Stabouli S, Kotsis V, Rizos Z, et al. Left ventricular mass in normotensive, prehypertensive and hypertensive children and adolescents. Pediatr Nephrol. 2009;24:1545-51. 
23

chey PA, Disessa TG, Hastings MC, Somes GW, Alpert BS, Jones DP. Ambulatory blood pressure and increased left ventricular mass in children at risk for hypertension. J Pediatr. 2008;152:343-8.

24. Urbina EM, Khoury PR, McCoy C, Daniels SR, Kimball TR, Dolan LM. Cardiac and vascular consequences of pre-hypertension in youth. J Clin Hypertens (Greenwich). 2011;13:332-42. doi:10.1111/j.1751-7176.2011.00471.x.
25

Hooman N, Hallaji F, Isa-Tafreshi R, et al. Ambulatory blood pressure monitoring, left ventricular mass index, carotid intima media thickness in children with renal parenchymal scar secondary to urinary tract infection [Abstract]. J Hypertens. 2012;30 (e-Suppl A):e111

\title{
Učestalost hipertenzije i kardiovaskularnih rizika u djece s ožiljcima na bubrežnom tkivu nakon mokraćne infekcije
}

\author{
N. Hooman, R. Isa-Tafreshi, SH. Mostafavi, F. Halladji, A. Tavasoli, M. Saeidy, M. Mehrazma, H. Otukesh
}

Hipertenzija je kasni ishod refluksne nefropatije i ožiljaka na bubrežnom parenhimu koji nastaju nakon mokraćne infekcije. Pretpostavili smo da bi se to moglo otkriti znatno ranije nakon epizoda mokraćne infekcije te procijeniti pridružene kardiovaskularne čimbenike rizika. Od 2009. do 2011. godine, u ispitivanje je uključeno 85 (67 Ž, 18 M) djece u dobi od pet do 15 godina sanamnezom febrilne mokraćne infekcije koja su bila praćena najmanje jednu godinu od prve epizode febrilne mokraćne infekcije. Praćene su sljedeće varijable: 24-satno ambulatorno praćenje krvnog tlaka (ambulatory blood pressure monitoring, ABPM), ehokardiografija, karotidni ultrazvuk, 99mcTc-DMSA bubrega, glomerularna stopa filtracije i mikroalbuminurija. Maskirana hipertenzija otkrivena je u 18,8\%, hipertenzija u 7,1\% i hipertenzija "bijele kute" u 9,4\% slučajeva. Prehipertenzija je zabilježena u $20 \%$ djece. Od 85 slučajeva 43,5\% ih nije pokazalo odgovarajući pad krvnog tlaka tijekom noći (non-dipper). Od 56 djece s hipertenzivnim i prehipertenzivnim parametrima na ABPM 9,1\% ih je imalo indeks lijeve ventrikularne mase veći od $51 \mathrm{~g} / \mathrm{m}^{2.7}(p>0,05)$. Značajna korelacija zabilježena je između nenormalnog krvnog tlaka i težine ožiljka na bubrežnom parenhimu ( $p<0,05)$. U zaključku, ABPM se može preporučiti za rano otkrivanje maskirane hipertenzije i nenormalnog kretanja krvnog tlaka kod sve normotenzivne djece sanamnezom opetovane mokraćne infekcije.

Ključne riječi: praćenje krvnog tlaka, ambulatorno; mokraćna infekcija; hipertrofija, lijeva ventrikularna; debljina intime-medije karotidnih arterija; rana dijagnostika 